\title{
Globalization, Multilateralism, Regionalism: from dilemma to multi-dimensionality ${ }^{\#}$
}

\section{Pavel Hnát}

Mutual relation between globalization, multilateralism and regionalism has went through profound changes in last decades. These changes are often interpreted as a way towards new world trade order. They are closely connected to parallel changes in world politics and societies. In the economic field, they however seem to be most significant and rapid. As a matter of this fact, they are often misunderstood and misinterpreted. Even though modern economic analysis suggests that the society can benefit from interaction between globalization and liberalization in a long run, general feelings are often negative. Based upon stressing the negative effects they can induce, reforms needed to face globalization often lack the public (and subsequently) political support.

The aim of this article is to conceptualize three dominant tendencies of the world economy more clearly, with respect to their former development and current understandings. Using namely the International Political Economy (IPE) as a tool of analysis, the article will aim at identifying main fields of beneficial interaction of the three tendencies and ways of eliminating their negative consequences. For this purpose, the article will firstly conceptualize all three terms with respect to current knowledge in the Czech Republic and abroad. Secondly, their mutual interaction will be studied in retrospective, i.e. with respect to their former development. Even today, the interaction between these three is often seen the same as before they went through the marked changes and thus leads to misleading interpretations. The changes induced in last decades will be thus emphasized. And thirdly, current conditions and prerequisites of positive mutual interaction will be suggested namely within the overall reform of the governance of global economy.

\section{Globalization, Multilateralism, Regionalism: basic definition of the concepts}

\subsection{Economic globalization}

Even though there are various impacts and results of globalization, the substance of the process must be sought in economy or even better in political economy of trade. Subsequently, globalization can be understood (almost exclusively) as "a growth of economic activity across national and regional borders, which reflects itself in increased movement of goods, services, property rights within trade flows and in movement of people within migration flows" (Nesadurai, 2002, pp. 1-12). Globalization as such is then a "process that

\footnotetext{
Article has been worked out within the framework of the Czech Science Agency Project "Regionalism and Multilateralism: Foundations of the New World Trade Order?" No. 402/07/0253, and the Research Plan of the Faculty of International Relations "Governance in Context of Globalised Economy and Society" No. MSM 6138439909.

* Ing. Pavel Hnát - research fellow; Department of World Economy, Faculty of International Relations, University of Economics, Prague, nám. W. Churchilla 4, 13067 Praha 3, Czech Republic; <hnatp@vse.cz>.
} 
occurs as a result of the logic of market integration, and which conceives of governance of globalization as oriented essentially toward the maximization of market efficiency in the interests of growth and development" (Phillips, 2005, pp. 23-24). Globalization, defined by this way, is deeply embedded in the economic bases of human society and especially in the technological progress. It is thus deeply connected with current world economy and its forces are, even if their negatives are considered, seen as effects that activate and speed up economic activity.

Should globalization be conceptualized precisely, it is necessary to understand that it is not a new phenomenon in the world economy. Using Oman's classification (Oman, 1996, p. 5), the first wave of globalization has occurred "during the 50 years prior the World War I." Geared by the Gold Standard, European Colonialism, Technological Revolution, and the emergence of giant joint-stock companies, ${ }^{1}$ the world has witnessed unprecedented trade growth and even stronger growth of inter-continental financial and migratory flows, namely between 1870 and 1914 . As quickly as it occurred, the first globalization's wave was interrupted by the World War, which gave birth to a renewed wave of trade protectionism and isolationism. The processes of internationalization, however, could not be stopped.

Second wave of globalization emerged during the "golden era" of post-war growth in the 1950s and 1960s. This period is characterized by the economic hegemony of the United States and stability of international monetary relations constructed upon dollar based Bretton Woods system of fixed-but-adjustable exchange rates. Besides the currency stability, a certain set of multilateral institutions (the heart of which was established by the Bretton Woods Institutions ${ }^{2}$ ) started to influence global environment and supported an unprecedented pace of international trade (initially, namely in goods, subsequently also in foreign direct investment driven capital markets). "That growth of trade, driven by the strength of economic growth, was facilitated by the substantial lowering of tariffs on manufactures in the developed countries under GATT (General Agreement on Tariffs and Trade) auspices, and within Europe by the creation of the Common Market, as well as by improved transportation and communications technologies, many developed during and prior to the War."

Dynamic growth of the world economy that occurred in most countries that opened to the global competition in the post-war years fostered a profound change in the economic policy applied - another factor that gears the globalization strongly, today. The change and the whole globalization wave was, however, stopped by major structural imbalances of the world economy that were revealed by structural and energetic crises in the 1970's and 1980 's.

Yet, the profound crisis of the global system gave birth to the new wave of globalization immediately. Since late 1980's current wave of globalization is to be observed. From its very beginning, it has been geared by a complex set of factors that were even multiplied by the end of bipolar division of the world. According to Oman (1996, pp. 10-15), namely these factor must be taken into account as sources of globalization to date:

1 Oman (1996) conceptualised the causes of globalization clearly. In all globalization's waves he identifies following fields of causes that gear the process markedly: (1) multilateral efforts on global trade stability; (2) political conditions; (3) technological progress and (4) changes in company management.

2 International Monetary Fund and the World Bank (International Bank for Reconstruction and Development) played a crucial role in forming global economic governance in those times. Moreover, third pillar of the Bretton Woods was envisaged to govern global trade liberalization - International Trade Organisation (ITO). As a consequence of a change in US administrative and Congress, ITO was not ratified and trade liberalization began to be governed by "provisional" articles of General Agreement on Tariffs and Trade (GATT). 
- deregulation,

- new technologies,

- financial globalization,

- opening of non-OECD countries,

- environment,

- and globalization of corporate activity.

Some of them will be explained further as they influence the interaction between globalization and multi-level liberalization markedly.

Deregulation is closely connected with the "remarkable revolution in economic policy in the early 1980's" (Helleiner, 2006, p. 77), "government across the world began to embrace more liberal policies that soon freed up market forces, both at the international and domestic levels". The neo-liberal economic policies then apply both to different levels of policy-making and to competitiveness (and its perceptions). Moreover, the above stated started to apply also for developing (or as Oman states non-OECD) countries more frequently. Their subsequent emancipation in global arenas soon became a focal point of the global governance effectiveness, which will be examined closely at the WTO case in 1.2 .

Secondly, the above-mentioned mix of factors soon resulted in unprecedented sharpening of global competition, which was enabled especially by technological progress and by the entrance of transnational economic actors into the world economy (Spindler, 2002, p. 13). Through the increased competition and influence of transnational entities on national and regional decision makers, the globalization markedly influences the way the economic policy and reforms are done. Globalization especially increases demands on national economies by strengthening global competition, by increasing the mobility of economic and human factors, and by a pressure on increasing own competitiveness in global environment.

Thirdly, globalization namely changes the balance between state (regulation) and market (free competition); primarily at the state level, however, since this level is traditionally resistant towards decreasing its influence (see the debate on principal IPE's contradictions e.g. in Phillips, 2005, p. 24 and pp. 92-99), it can be more often seen in transnational (regional and global) instruments, today. However, the relation between free market forces and state efforts to regulate them are influenced by the globalization towards more flexible economic environment, state still has its important functions and remains a foundation of international relations. Yet, there is a certain globalization's pressure on the shift form traditionally understood welfare state to the competition state. An important aspect of this shift is however a statement that the welfare state is not threatened by the globalization and market forces but by its own, too interventionist, arrangements; "the welfare state interventions themselves reinforce the necessity of marketisation (i.e. shift towards market) and freer competition" (Spindler, 2002, p. 13).

\subsection{Economic liberalization - global and regional perspective}

Being partly a driving force, partly a consequence of globalization, the economic liberalization has become a firm component of global trade order the importance of which grows even today. Yet, even though the emphasis of this paper is put on a specific segment of the economic liberalization - to abolishing the barriers in international economic relati- 
ons and subsequent market integration - the process of economic liberalization went through profound changes and is based on various levels of policy making. As such it is frequently analysed as a marked case of the multi-level governance system today. Before inspecting the current and latest theoretical frameworks, the basic ideas must be, however, conceptualised.

Multilateralism has already been mentioned above. It is represented by the efforts on worldwide liberalization of international relations, which started in the field of trade in goods when the GATT was signed, and developed into broader fields of trade in services, investment, agricultural products, public procurement, and intellectual property rights with its more sophisticated successor - the World Trade Organization (WTO). However this development is generally known, its connections to globalization and changing global conditions are not usually analysed; even though they influenced the position of multilateralism as a principal part of economic governance comprehensively. Winter's (1991, p. 172) analysis of the political economy of multilateral liberalisation suggests three principal factors of GATT's importance for the openness and growth of the world economy, that can be applied to the institutional bases of the WTO today as well. Firstly, "reciprocity (of trade talks) turns business's wish for market into a liberalising force" and the multilateral talks thus become a strong impetus in microeconomic force of individual firms and their influence on national government. Moreover, with the upsurge of transnational corporations (TNC), globally free trade has an ever-stronger advocate. Secondly, even GATT, however its legal binding was relatively week, introduced "legal-based and transparent policy toward free trade" which represents "a strong counter-argument to domestic lobbies seeking protection". Once more, this argument applies even stronger for the institutionally more sophisticated WTO. And finally, "by offering some escape from crushing competition, GATT has allowed industry to experiment with liberalisation" and as such it allowed the trade liberalisation to spill-over from temporary and limited commitments toward a complex agreements on trade, services and intellectual property rights.

Besides the internal factors based on the political economy of the process itself, multilateralism has been strongly influenced by globalization. Together with Tussie (2003, p. 99), we can assume that "globalization is having a profound effects on the political economy of trade since more countries than ever before have been persuaded to push aside protective barriers and compete for world markets. These new entrants include a wide range of developing countries and the former Soviet or Eastern bloc economies".

As a matter of this fact, multilateralism changes qualitatively (even GATT became broader scale, which was definitively confirmed by the signature of GATS and TRIPS under the WTO framework); quantitatively (from original 23 GATT countries, WTO had 151 members in 2007 and further countries (e.g. the Russian Federation) are waiting for full membership) and covered almost 95\% of global trade (Steinmetzová, 2005, p. 19); and formally (institutional framework of the WTO is much stronger and tries to influence state authority significantly). ${ }^{3}$ Both globalization waves that stroke the institutional arrangement of GATT resulted in following impacts of the globalization to trade and its global governance (Tussie, 2003, pp. 103-105):

- since the 1980 's, trade has been altered by the internationalisation of production, distribution and marketing of goods and services, as well as the increasing flows of capital and investment which underpin trade;

3 These three types of changes (qualitative, quantitative and formal) are traditionally designated to regionalism when New Regionalism is defined. e.g. according to Cihelková et. al. (2007, p. 20). 
- with the addition of new participants in the world trading system (developing countries seeking economic prosperity and transforming countries searching for reintegration into the global economy) globalization increased capital and services flows rapidly, resulting from changes in technology and policies;

- globalization created a new pattern of growth and competition in the world economy by creating unprecedented growth opportunities (e.g. in East Asia), which challenge traditional leaders of the world economy - including United States, EU and Japan.

Moreover, current wave of globalization combined with the changes in world order (explained above) resulted in the most recent changes in multilateralism, which started in 1986 by launching the Uruguay Round of the Trade Talks. They "expanded the scope of the WTO" and "deepened its governance" (Mortensen, 2006:173-179) by including the issues of international standards, intellectual property rights and services into the scope of the WTO. Additionally, more sophisticated dispute settlement mechanisms increased the influence of WTO on the policy-making in its member states markedly. In opposition to hardly institutionalised GATT, WTO became a firm component of trade governance with a large impact and influence on global, regional and national transactions. Together with this process it however entered into quite a deep crisis, which is more than ever related to the complexity of global governance. Virtual global membership increased the diversity in demands and approaches of WTO members. The problem of diversified membership and lack of dynamics is, however, not a new one within the GATT/WTO system, and according to many it even gave birth to another level of trade liberalization - to regionalism (as explained further).

Regionalism represents a worldwide dynamics of market integration, which went through profound changes closely connected to the waves of globalization as well. Initially regionalism was namely understood as a regional form of protection from the forces of globalization and trade liberalization - Manuela Spindler (2002, p. 3) explains the substance of "old regionalism as a kind of protection against forces of globalization and competition, which represented efforts on national protectionism at a regional level and has usually been associated with the protectionist provisions of the so-called embedded liberalism". Old regionalism has spread across the world economy namely since 1950's and, however, it gave birth to some of the most impressive cases of integration groupings (European Union, European Free Trade Association, Association of South East Asian Nations, Andean Community and many others) it limited itself in three main aspects.

Firstly, old regionalism limited itself to creating geographically based trade blocks (national protectionism at a regional level defined above). These blocks were often labelled as fortresses ${ }^{4}$, which opened the trade within their area but shifted them to their external boarders. As such many of the initial trade blocks were trade diverting and the multilateral trade talks were soon seen as the only way to force them to liberalise externally. Secondly, old regionalism limited itself in its global reach, which was inevitable namely due to the bipolar division of the world economy in those days and due to a reserved attitude of the United States toward regionally limited trade liberalization. Being the most competitive economy, the United States supported the GATT efforts exclusively and did not enter any of regional integration since 1980's (the reasons lies in the effects of globalization and will be explai-

4 Most typical example here is the development of today's European Union (EU). In their initial stages, the European Communities were strongly criticised for their external barriers (Fortress Europe) that were only decreased due to the pressure of multilateral forum in 1970's when comprehensive external policies and common trade policy of the European Communities (EC) were introduced. As a matter of ever-stronger external competition and globalization, the EC/EU soon became strong advocates of globally freer (and regionally more advantageous) trade, since then. 
ned further). And finally, old regionalism limited itself in its scope and similarly as the GATT process liberalised the modern aspects of trade only as a result of a spillover effect in its most developed cases. An important aspect must however be emphasized here, many trade liberalising practices that are broadly used by the WTO today, were originally implemented (on what Winters calls experiment bases) in the most advanced regional integrations, and namely in the EC. The explanation is, however, quite simple: limited geographical scope, number of participants and their extensive economic relations enable the regional integrations to liberalise trade and related aspects more quickly and effectively compared to the global processes of GATT or WTO. All in all, during the initial stages, regionalism was seen (and usually correctly) as a threat to the global liberalization as it breeched its crucial principle - the precept of non-discrimination.

Being more or less effective (namely in developing regions, the effects of inward-oriented regional integration were more than doubtful), regional based liberalization became a firm component of the trade rules, which was, however, seen as a complication of the multilateral efforts by many (see the explanation in 2.1). On the other hand, both regionalism and multilateralism had been changing and especially due to the increase in diversity between the GATT members, regional solutions of free trade became more and more popular. Moreover, due to their concourse with the multilateral liberalization efforts, they were also more and more effective since their trade-diverting effects were partially eliminated by overall decrease in barriers to trade and by their external strategies. Additionally, the development problem soon created a certain space for implementing the regional strategies between poor countries, which should enable them to compete more effectively in global arenas (the Enabling Clause will be specified in 2.1 as well).

All in all, sharpening of global competition and lack of dynamism within diverted GATT has become a crucial motive for regionalism namely after the crises of 1970's and 1980's. As a marked result of this development, namely the United States started to form their regional strategies, which induced expressive regionalism movements across the world. And another result of the crisis development must be taken into account here: a "remarkable revolution in economic policy in the early 1980's" which was already mentioned as an impetus for globalization. Applied to the case of in-ward oriented regionalism, the overall shift in economic policies played an important role in "opening of regionalism" as well. Final factor was however (similarly as for globalization itself) added by the end of bipolar division of the world, which increased global competition on one hand, and increased the scope for applying regionalism, on the other.

A subsequent upsurge of globalization changes the quality of regional integration markedly. Since globalization decreases the influence of states on the economic environment, utilization of region-wide economic potentials and maximization of immediate gains form mutual trade is seen as the way to increase one's own competitive positions in a globalized world. The qualitative shift in regionalism is, however, closely connected also to the changes induced by globalization at the national level. New and outward-oriented regionalism can firstly promote the necessary structural and economic reforms at national level, and secondly encourage progress in multilateral fora. Both aspects are however empowered by globalization and its challenges. Together with Tussie (2003, pp. 112-114) we can assume that:

- New Regionalism is being driven more by markets and less by policy, which results from the fact that globalization changes the balance between state (regulation) and market (free competition);

- from the institutional-building point of view, regional integration can additionally become a force, which is able to overcome resistance towards deregulation and opening at 
the national level, which seems to be the only reaction to globalization and further boosts it;

- New Regionalism bridges the traditional division between developed and developing countries, as there is a certain shift in North-South Regional Trade Agreements (RTAs) from non-reciprocal trade preferences towards reciprocal cooperation on the basis of complex RTAs (namely in the US approach, however, recently also in that of Japan and $\mathrm{EU})$;

- New Regionalism is more diverse in its geographical coverage and becomes truly a global phenomenon (through the increase of transregional arrangements, which connects partners form different macro-region of the world economy);

- new forms of regionalism, especially bilateral (between only two countries) and biregional (between an RTA and another country or group of countries) agreements, do not tend to create trade blocks as they are usually transregional and intended to diversify trade relations.

A brand new quality of regionalism is often explained by a brand new form of integration that starts to be the most frequent form of integration today. It is usually labelled as Complex Regional Trade Agreement and, however, it formally builds upon the free trade area concept, it has progressive features of the common market, too. Its broad scope is based especially on complex liberalisation of all economic sectors, on liberalisation of services, capital and work force, which is followed by relatively strong rules for procurement, dumping and countervailing measures under a strong surveillance mechanism. All in all, it, however, has relatively weak institutional structure, which is predominantly based upon intergovernmental cooperation. There are, of course, significant differences in the level of implementation and ambitions between RTAs that were given as examples above. These differences can be partially explained by the distinction in economic levels of the countries involved in them (i.e. North-North RTAs usually aim at deeper mutual integration more swiftly, as their countries firstly have greater interest in liberalizing the modern parts of their mutual trade and secondly their real convergence is usually higher, making integration less complicated). The more important part of the answer, however, lies in the approaches of the leading actors of regionalism to the RTAs they negotiate (e.g. United States generally prefer more rapid and liberal schemes of market integration without special policies dealing with regional disparities).

Moreover, globalization influences regionalism quantitatively; as openness is seen as the only answer to the challenges of global competition both in developed and developing countries, regionalism spread out as a tool of countries' integration into the regional and global economy. Even more importantly, however, globalization changes the quality of regional integration markedly. The new logic of regionalism is thus more often seen in the efforts on increasing national and regional competitiveness in globalized world economy. Subsequently, regionalism's flexibility, comprehensiveness and broader scale of economic liberalization (which increases the economies of scale and support investment, innovations and technological progress) are the main effects, by which regional integration can promote competitiveness. As such open and outward-oriented regionalism can hardly be compared with its previous waves - the same applies for its interactions with globalization and multilateralism. 


\section{Globalization, Multilateralism, Regionalism: understanding the mutual relations in retrospective}

\subsection{Dilemma between multilateral and regional liberalization: a traditional approach}

Analysis of the multilateralism - regionalism relationship done so far has been predominately based upon the building blocks versus stumbling stones argument introduced by Baghwati. As a focal point of this argument, multilateralism is a first best option in trade liberalization, which can be eroded or supported by partial solutions of trade liberalization, i.e. by regionalism. Focal theory of this approach is the customs union theory introduced by Jacob Viner, which has formed the mainstream attitudes towards regional integration for the whole decades of the $20^{\text {th }}$ century.

Customs union theory builds upon an analysis of positive and normative effects of trade liberalization. Based upon Viner' ${ }^{5}$ theories, regionalism constitutes a change in trade flows, which can lead to the trade creation or trade diversion; trade diversion then affects non-member countries and decreases overall wealth. Trade creation means that as a matter of preferential treatment, domestic production (country A) is supplemented by exports from RTA partner (country B), which produces the goods more effectively (at lower cost). As such, the trade creation leads towards increase in wealth of the regional integration without affecting third countries (country C). All in all, it is a positive effect both for RTA's members and non-members. Trade diversion, on the contrary, means that more effective (less expensive) goods exported from non-member country (C) so far, is supplemented by more expensive goods produced in RTA partner (B) as a result of the preferential treatment. Trade diversion builds upon an abolishment of administrative barriers to trade and not upon the overall economic effectiveness. As a result, non-member country is affected (by diversion of its exports) and also the overall wealth of the regional integration is spent ineffectively.

More sophisticated explanation (which goes sometimes above Viner's initial theories) is expressed in Chart 1. It shows basic demand and supply curves in country A and assumes fixed prices in countries B and C. Equilibrium prior the customs union introductions is given by the exports from country $\mathrm{C}$, the prices of which $P_{C}(1+t)$ are lower than those form B $P_{B}(1+t)$. Domestic production is expressed by $h_{t}$ and domestic consumption by $q_{t}$. Incomes form customs duties are given as a sum of $C$ a $E$ areas.

Introduction of customs union between $\mathrm{A}$ and $\mathrm{B}$ shifts the equilibrium as a result of $\mathrm{B}$ import prices (due to the preferential treatment shown by $P_{B}$ ) being lower than $P_{C}(1+t)$; new equilibrium expresses domestic production $h_{u}$ and domestic consumption $q_{u}$. Trade creation was caused by elimination of a part of domestic production $\left(h_{t}-h_{u}\right)$ by exports. Trade diversion, however, switched exports form $\mathrm{C}$ to exports from $\mathrm{B}$.

Impacts on wealth in the country that grants the preferences are following:

- consumers' surplus increases by $A+B+C+D$, since consumption increases from $q_{t}$ to $q_{u}$. Of which, A is lost by producers the production of whom is decreased and $\mathrm{C}$ by government that loses income from customs duties;

- net income is given by a more effective allocation of consumers' spending (area B) and by sources of domestic producers that have been allocated ineffectively (area D) - this area represents country A's income from trade creation;

5 Basic explanations and case study based upon Winters, 1991, pp. 176-180. 
- part of former customs duties incomes (area E) is, on the other hand, lost by country A and granted to the producers from county B. This loss represents trade diversion for country A;

- overall effect is represented by $B+D-E$ and can be both positive and negative.

\section{Chart 1: Customs Union (basic situation for one country)}

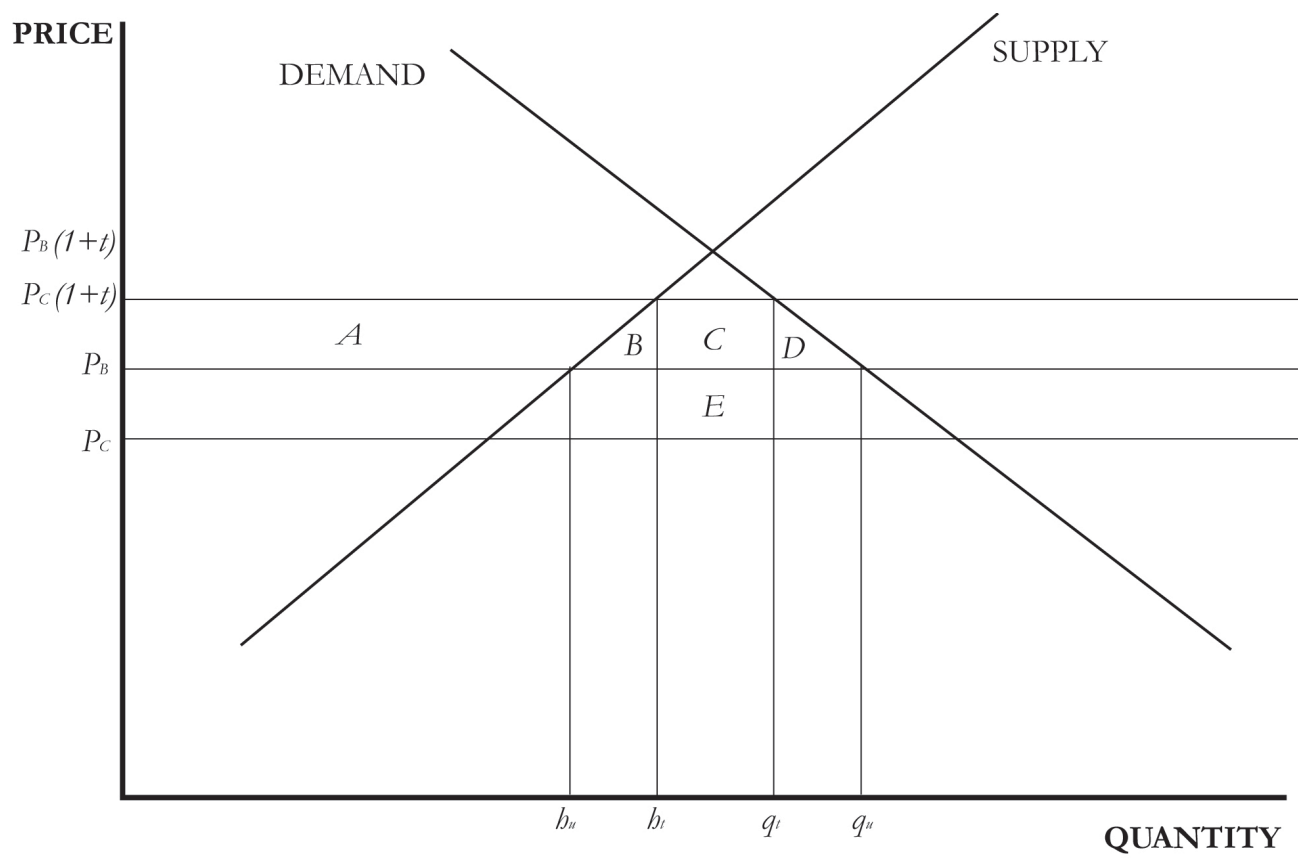

Source: Winters, 1991, p. 178.

Analysis can be further improved by including more countries and more goods; however, the overall theoretical outcome is not changed then. In stead, the economic theory seeks for stating the conditions, under which the customs unions are more trade creating than trade diverting. Winters suggest that the customs union is the more favourable:

- the greater it is as it increases the chance to find the most optimal producer;

- the higher the customs duties prior its introduction are as they cause grater production and consumption distortion before the union is agreed;

- the lower the customs duties stated by the union are as lower duties eliminate the trade diversion risk;

- the greater the differences between productions of RTA countries;

- the greater the differences between prices of corresponding goods in partner countries are as they lead toward greater specialization.

Based upon the theoretical conclusions of the customs union theory, the institutional relation between multilateralism and regionalism has been formed and prevailed even after the upsurge of New Regionalism in late 1980's. Being governed by the will to eliminate negative effects on third countries, rules for creating the regional integration agreement (na- 
mely the free trade agreement or customs union) were entitled into GATT. Under Article XXIV. certain conditions are stated that must be fulfilled by the GATT members who are willing to grant preferential treatment to another country (breech of the non-discrimination principle). Firstly, RTA (FTA or CU) cannot increase barriers to trade from non-member countries above the level that had existed before the RTA was signed. Secondly, barriers to trade (namely the custom duties) must be eliminated completely within the RTA, i.e. decreased to zero. Additionally, elimination must be conducted according to a time schedule that cannot extend ten years. Thirdly, the RTA must cover substantially all trade. Clearly, these rules are designed to eliminate trade diversion, however, their legal enforceability has been week namely due to a vagueness of the term 'substantially all trade' and due to the fact that GATT has now tools how to force its member states not to sign regional agreements.

However the overall attitude towards RTAs had not changed for long, there has been some development during the existence of GATT and after signing GATS. In late 1970's, increased membership of developing countries led to signing an enabling clause, which grants special conditions for signing RTAs (FTA and CU again) between developing countries or for developed countries granting special treatment to the developed ones. Enabling Clause namely grants less strict conditions for these agreements and together with general opinion in 1970's it allows the developing countries to 'prepare' for global competition. However, there are successful cases of regionalism registered under the Enabling Clause; it is not very frequently used even by the developing countries, today.

The same approach as for goods was applied in mid 1990's as well by signature of GATS and establishing the WTO. For agreements in services, which usually establish higher forms of economic integration (complex RTAs or common markets), equivalent conditions have been stated by the GATS agreement: same or lower barriers to non-members, elimination of all barriers between partners and complex coverage (however, it is even more complicated to define when trade in services is concerned).

As far as the political economy of mutual relation of multilateralism and regionalism in these days is concerned, it was most explicitly emphasized by Bhagwati, who introduced the building stones stumbling blocks debate to show main arguments of positive and negative effects of regionalism on multilateralism, respectively. The debate is however governed by the same attitude, i.e. it understands multilateralism as the best option for global trade and seeks for conditions under which the negative effects of regionalism on global efforts can be ensured. Main arguments at the stumbling stones side of the debate, which concentrates on the negative impact of regionalism on multilateralism, can be summarized as follows (IBRD, 2005, p.133):

- regionalism may promote costly trade diversion rather than efficient trade creation;

- proliferating RTAs absorb scarce negotiating resources (especially in poorer WTO countries) and crowd out policy-makers attention from multilateralism;

- competing RTAs may lock in incompatible regulatory structures and standards, and may result in inappropriate norms for developing partners;

- by creating alternative legal frameworks and dispute settlement mechanisms, RTAs may weaken the discipline and efficiency associated with broadly recognized multilateral framework rules.

On the other hand, the building blocks arguments suggest that under special conditions (broader scale of RTAs, external openness of regionalism e.g. as applied in South-East Asia today (Stuchlíková, 2007, p. 365), support for the internal reform process and greater geo- 
graphic diversity of regionalism etc.), regionalism can foster multilateral efforts on globally freer trade. The arguments are usually shown as follows (Cihelková et. al., 2007, p. 92):

- RTAs can help sensitise domestic constituencies to liberalization and keep the stakes lower to allow for progress on trade;

- expanding the number and coverage of successive RTAs can erode vested opposition to multilateral liberalization;

- most effective RTAs introduced many of the liberalization tools more effectively and sooner than the GATT or WTO;

- $\quad$ RTAs can lead toward a greater consensus between trade partners and ease the agreement on global liberalization within the multilateral institutions.

All in all, general attitude of multilateralism towards regionalism has not changed much throughout the $20^{\text {th }}$ century and was characterised by the "dilemma approach" (Tussie, 2003, p. 114): multilateralism understood as a first best option, regionalism only as the second best one if the pace of multilateralism is not sufficient enough. GATT/WTO stated the conditions of mutual interaction clearly, however their ability to control RTAs' compliance with GATT XXIV. or GATS V. provisions remained low. Major changes in the overall feelings can be seen only today and are strongly connected with modern analyses of New Regionalism, its new theories (see e.g. Söderbaum - Shaw, 2003), and due to the continuing effects of globalization on both regionalism and multilateralism.

\subsection{Towards multi-level governance of trade: mutual relation revisited}

Being geared namely by the challenges of globalization, both multilateralism and regionalism has went through gradual changes throughout the $20^{\text {th }}$ century. These changes are (as described in Chapter 1) characterised by an ongoing deepening and widening of both phenomenon. Deepening represents the greater scale which has moved from elimination of trade in goods barriers towards complex rules for freer movement of goods, services, intellectual property rights, labour force and more transparent competition based upon dispute settlement mechanisms, procurement and competition rules as well as general callings for transparency and openness. Widening is seen in an increased membership, i.e. in ever-greater involvement of world trade actors both in multilateral and regional provisions of economic liberalization. In general, deepening and widening of integration processes (multilateralism can be seen as a special case of integration here) are seen as mutually positive processes that can expand the effects of liberalization (more countries involved in ever better institutional provisions). Yet, as a matter of ever complex situation in the world economy increase in membership and ever greater proliferation of regional trade agreements makes the consensus in multilateral fora more and more complicated. As a matter of this fact, many countries that were supporting the multilateral way of liberalisation exclusively so far, started to apply regional provisions ${ }^{6}$ in their trade policies as well and complicated the whole situation further.

6 Most typical example with greatest consequences is the case of United States. Being a most competitive economy, United States exclusively supported the GATT process ever since 1940's. Increased competition pressures in 1970's (initially namely the competition from Japan and European Communities), however, showed that their competitiveness started to be challenged markedly. Moreover, the pace of the GATT process started to be too slow (taking the increased membership of developing countries with other interests) to fit demands of the US economy seeking for free movement of services and capital and stronger intellectual property protection. As a matter of these factors, United States has started to apply regional strategies to trade liberalization since 1980's (e.g. with Canada, 
Moreover, late 1980's brought marked institutional changes to the world order established so far; subsequently, the process of widening took unprecedented pace (as a matter of transforming countries' willingness to tie with the most successful economies on the one hand, and as a matter of trade and investment opportunities in newly emerging countries on the other). GATT and its successor WTO increased the number of countries involved and namely several enlargements had an indisputable global impact: e.g. China became a member of WTO in 2001 and Russian Federation finalizes its accession process today. Yet, the pace of regionalism increased even more markedly. New Regionalism saw an eminent increase in the number and forms of regional integration, which definitively underpinned the necessity of seeking various ways of interaction (between multilateralism and regionalism) in stead of seeking for the ways of eliminating or challenging each other.

With introduction of the governance concepts, ${ }^{7}$ the overall movement towards more flexible, open, competitive and outward-oriented approach in international economic relations started to be seen as a way of effective combination of various levels of economic governance; i.e. as well of multilateralism and regionalism. In this perspective and taking their rapid development into account, both levels seem to correspond to each other in a larger scale than before. As such, it seems more reasonable today to study the interaction between regionalism and multilateralism not as a 'dilemma' (Tussie, 2003, p. 99), but as a source of increased dynamics of economic governance as a whole. In other words, "regionalism and global free trade cannot be seen as mutually exclusive options, whereby interest in one diverts interest in the other. Regionalism rather reflects that countries are choosing to forge ahead faster or further than the multilateral track affords, as a matter of which trade between regions cannot grow as fast as within them. Multilateral rules, however, provide RTAs with necessary underpinnings, especially in the highly controversial issues. On the other hand, multilateralism relies on the net of RTAs, which allows gradual liberalization" (Tussie, 2003, p. 114) and foster market integration between different regions. Moreover, both processes are geared by globalization today, which forces states (as the principal actors of both of them) to apply more open and mutually compatible solutions for economic reform.

Yet, should the deepening take the similar pace as widening, namely the emphasis on the transparency and better governance had to be especially fostered in both processes. In the multilateral agenda, it was clearly represented by the new principles of the WTO and by its reform - namely brought in by the Uruguay Round of trade talks. "The Uruguay Round, which was concluded in 1994, has had three important consequences for regional arrangements. Firstly, it led to the adoption of the 'Understanding on the interpretation of

Israel). End of the bipolar division of the world changed their strategy further, which was definitively confirmed by launching the North American Free Trade Agreement (NAFTA) in mid 1990's. After NAFTA's success the pace of US driven regionalism was undisputable. Today the United States diversify their regional strategies between Americas, Asia and Pacific, and North Africa; and apply different forms and levels of RTAs. Where there is not a positive prospect of region-wide provisions in a short run, bilateral RTAs are soon implemented with the most open (not only economically) countries (e.g. Chile in Latin America; Bahrain in Arabic Peninsula; Israel or Jordan in Middle East etc.).

7 It is clear today that governing complex societies facing globalization requires new modes, the set of which is usually conceptualised as governance. The term itself is defined in various manners, however, to our understanding following definition quoted from Payne (2005, p. 64) is the closest: "Governance is a descriptive label that is used to highlight the changing nature of the policy process in the late twentieth century. In particular, it sensitises us to the ever-increasing variety of terrains and actors involved in the making of public policy. Thus governance demands that we consider all the actors and locations beyond 'the core executive' involved in the policy making process." It emphasises clearly that the substance of governance lies in a more efficient involvement of various level of decision-making in an opposition to almost exclusive role of nation state or state-based organizations (based namely upon the post-war evolution). 
Article XXIV. of the General Agreement on Tariffs and Trade 1994', which is part of the founding documents of the WTO. This understanding attempts to clarify some of the criteria and procedures for assessing agreements notified under Article XXIV. as well as to improve the transparency of all such agreements. Secondly, the Uruguay Round also gave birth to the Article V. of the GATS as far as services are concerned. Finally, one should note the establishment, at the beginning of 1996, of the Committee on Regional Trade Agreements (CRTA). The main task of the CRTA is to assess the compatibility of FTAs and customs unions with the provisions of the GATT and the GATS. Since there is an important backlog of notified but unexamined agreements, the CRTA will have its work cut out. It also has a mandate to examine systemic issues, but as yet, it is too early to judge how successful it will be in this respect" (Nagarajan, 1998, p. 7).

However, there was much progress in the matter of WTO's supervision to numerous RTAs the situation has not been sufficiently solved so far, leaving too much space for the RTAs' member countries not to inform the WTO complexly. In this respect, the General Council Decision from December 2006 on Transparency Mechanisms for Regional Trade Agreements (WTO, 2006) is the most recent achievement, which refines member states' obligations to inform the CRTA early and complexly about the data needed to decide about the RTAs' compliance with the respective provisions. Together with gradual enforcements of the related WTO provision, the upsurge in the RTA's number reflected itself in the number of agreements notified ${ }^{8}$ to the WTO (see Tab. 1).

Tab. 1: Number of RTAs notified to the WTO according to GATT/GATS provisions (as of 2 October 2007)

\begin{tabular}{|l|c|c|c|}
\hline \multicolumn{1}{|c|}{ WTO Provision } & Accessions & New RTAs & Total \\
\hline GATT XXIV (FTA) & 2 & 109 & 111 \\
\hline GATT XXIV (CU) & 6 & 7 & 13 \\
\hline Enabling Clause & 1 & 20 & 21 \\
\hline GATS V & 2 & 47 & 49 \\
\hline Total & 11 & 183 & 194 \\
\hline
\end{tabular}

Source: WTO, http://www.wto.org/english/tratop_e/region_e/summary_e.xls.

Yet, RTA transparency mechanism still remains relatively week and cannot ensure full compliance of the numerous RTAs with the WTO provisions. Moreover, consensus-based provisions of the respective articles are not sufficient enough to eliminate eventual negative effects (introduced in 2.1) of regionalism at all. As a matter of this fact, even the WTO has adopted a different approach towards the regional initiatives which is based upon three basic elements: (1) enforced CRTA mechanism and continuing pressure on member states to inform the WTO bodies about RTAs in force and about RTAs projected; (2) transparency mechanisms; and (3) just and complex information about the developments and effects of regionalism. Moreover, with Pascal Lamy (former EU Trade

8 Every regional trade agreement signed or entered by the WTO must be notified and becomes a part of the WTO notifications list, which is updated regularly. It is available at the WTO website. 
Commissionaire) at the position of WTO Director General, also the official speeches ${ }^{9}$ started to pay attention to the mutual complementarity of the inevitable coexistence of multilateralism and New Regionalism (in Lamy's words: "a new generation of regional trade agreements").

The project of a multi-dimensional governance of trade, i.e. a effective combination of various levels of decision-making, is enabled only by a substantial changes in the economic policies applied by the New Regionalism agreements. As explained in 1.2, New Regionalism consists of various progressive and outward-looking features that make the separate levels of economic liberalization more compatible. Today's regionalism is firstly more broad and complex in its approach to economic liberalization (the scale of RTAs has broadened into the most dynamic areas of international economic relations such as free movement of services, capital and workers, competition policy, intellectual property rights, surveillance mechanism). It has, secondly, a virtually global scale, which reduces the risk of creating competing trade blocks that could hinder multilateral talks. And thirdly, New Regionalism seems to aim at consistency with the multilateral provisions, at formulation of straightforward and clear rules of economic liberalisation, ${ }^{10}$ which can be combined even there, where various levels of economic liberalization overlap each other.

\section{Conclusion}

Today's world economy has been significantly different from its previous developments. Namely globalization must be seen as the principal driving force of its changes. Based upon the analysis of its Political Economy, globalization markedly influences the tools used by the nation states to govern their economic environment. As a matter of both economic and political changes at the end of 1980's, open-oriented economic policies motivated by the clash for global competitiveness, started to be applied more broadly (which contrasts markedly to the post-war developments in most world's regions). With the overall openness, trade liberalization became even a stronger importance and as a matter of this fact, it must be seen as the most influential tool of global economic governance, today.

In ever-complex global economic relations, both globalization and economic liberalization are however multi-dimensional phenomena, the effects of which differ on various levels of decision making. Especially for the liberalization efforts, the multidimensionality has become a principal approach that enables us to study the internal complexity of the whole process. Most effective tool of external openness has always been an unilateral approach based upon individual commitments of states to eliminate trade barriers on its boarders. With upsurge of uncertainties of the global world, the decreased dynamics of unilateral approach had to be fostered by the multilateral efforts, in the post-war period. Being strongly supported by the increase of transactional trade and financial flows, GATT/WTO created legal-based and transparent policy toward free trade worldwide. Yet, also its pace started to be complicated by various factors, within which

9 For example, within his speech in India at the beginning of 2007, Pascal Lamy emphasized that the future of world trade order lies in "a strong and modern multilateral trading system coupled with regional trade agreements which amplify rather than undermine its benefits. A strong multilateral trading system complemented - not substituted by a new generation of regional trade agreements", which are thus like "pepper in the multilateral curry".

10 In its most developed form, such an out-ward looking regionalism is often conceptualised as a special category open regionalism. Even today, it can be seen namely in the Asia Pacific region where applied most significantly be the Individual Action Plans of the Asia Pacific Economic Cooperation (APEC) or by the Association of South-east Asian Nations (ASEAN). 
namely the increased membership and diversified interests must be emphasized. It was thus no surprise that being challenged by the structural reforms and new competitive threats, states slowly slipped towards new tools of market opening after the 1980's - regionalism got an unprecedented pace. Subsequent situation in the world thus led towards a complex system of rather resistant national states, market opening region-based RTAs and worldwide-consensus driven multilateral institutions.

Facing the new reality, economic theory started to seek new approaches to the mutual interaction within this complex system - the dilemma approach was exchanged by seeking for the conditions of positive coexistence of various dimensions of the system. Once again, globalization studies played a crucial role here, as globalization was seen as a reason for profound changes that economic liberalization as a tool of economic policy has gone through. Both multilateral and regional liberalization firstly expanded their scope and deepened their governance. Moreover, being the response to the same challenge, both processes started to be more complementary to each other. New Regionalism - an outward-oriented, open and globally driven upsurge of new forms of market integration took main step in this respect.

Yet, there are still many concerns about the sustainability of the new multi-dimensional governance based world trade system. They are mainly induced by the unprecedented pace of regionalism which leads toward mutual proliferation of various trade and investment regimes and by the concerns about the position of developing countries that cannot simply compete with the key players of the world economy. From the WTO's point of view, these concerns reflect in ever more sophisticated transparency mechanisms, which should force the RTAs' parties to provide the multilateral forum with complex information about the regimes they provide. From the regional point of view, no coherent movement towards single approach towards the complementaritry issue can be observed. On the other hand, the most progressive features of the New Regionalism (based upon openness and competition driven market integration) seem to implicitly lead towards better compatibility with multilateral efforts. As such, namely these trends in regionalism (so far typical namely for South East Asia and Pacific, North America and selective RTAs in Europe and Latin America) must be especially fostered.

Only then the extraordinarily fragile vision of global economic governance based upon a multi-dimensional perception of the mutual influences between multilateral and regional ways of liberalization may prevail. Being sophisticated by the increased transparency and outward-competitiveness seeking measures, it should be able to answer the main challenges of the $21^{\text {st }}$ century more effectively than the fragmented global system so far. 


\section{References}

CIHELKOVÁ, E. et. al. (2007). Nový regionalismus: teorie a prípadová studie (Evropská unie) [New Regionalism: Theory and a Case Study (European Union)]. Prague, C. H. Beck.

HELLEINER, E. (2006). Alternatives to Neo-Liberalism? In STUBBS, R., UNDERHILL, G. R. D. (eds.). Political Economy and Changing Global Order. Canada, Oxford University Press.

IBRD (2005). Global Economic Prospects: Trade, Regionalism, and Development. Washington, IBRD.

LAMY, P. (2007). Regional agreements: the pepper in the multilateral curry. Speech given on 17 January 2007, India. http://www.wto.org/.

MORTENSEN, J. L. (2006). The WTO and the Governance of Globalization. In STUBBS, R.; UNDERHILL, G. R. D. (eds.). Political Economy and Changing Global Order. Canada, Oxford University Press, pp. 294-305.

NAGARAJAN, N. (1998). Regionalism and the WTO: New Rules for the Game? Economic Papers No 128, June 1998. Brussels, European Commission.

NESADURAI, H. (2002). Globalization and Economic Regionalism: A Survey and Critique of the Literature. Working Paper 108/02. Warwick, Centre for the Study of Globalization and Regionalisation.

OMAN, Ch. (1996). The Policy Challenges of Globalization and Regionalisation. Policy Brief No. 11. Paris, OECD.

PHILLIPS, N. (2005). Globalizing International Political Economy. Houndmills, Palgrave Macmillan.

SPINDLER, M. (2002). New Regionalism and the Construction of Global Order. Working Paper 93/02. Warwick, Centre for the Study of Globalization and Regionalisation.

SÖDERBAUM, F.; SHAW, T. M. (2003). Theories of New Regionalism. Houndmills, Palgrave Macmillan.

STEINMETZOVÁ, D. (2005). Světová ekonomika. In Proměny světové ekonomiky - teorie a realita. Prague, Oeconomica, pp. 1-44, 2005.

STUCHLÍKOVÁ, Z. (2007). Redefining Roles and Positions of Japan and China in East Asia: Implications for Regional Governance. In ROLENC, J. M. (ed.). Crucial Problems of International Relations through the Eyes of Young Scholars. Prague, Oeconomica, pp. 352-368.

TUSSIE, D. (2003). Regionalism: Providing a Substance to Multilateralism? In SÖDERBAUM, F.; SHAW, T. M. (eds.). Theories of New Regionalism. Houndmills, Palgrave Macmillan, pp. 99-116, 2003.

VYMĚTAL, P. (2005). Proměny governance [Transformation of Governance]. Prague: Centrum ekonomických studií VŠEM.

WINTERS, A. L. (1991). International Economics. $4^{\text {th }}$ Edition. London, Harper Collins Academic.

WTO (2006). General Council Decision from December 2006 on Transparency Mechanisms for Regional Trade Agreements.http://www.wto.org/english/tratop_e/region_e/region_e.htm. 


\title{
Globalizace, multilateralismus, regionalismus: od dilematu k multidimenzionalitě
}

\author{
Pavel Hnát
}

\begin{abstract}
Abstrakt
Globalizace, multilateralismus a regionalismus patři k nejvýraznějším tendencím současné světové ekonomiky. Jejich vzájemný vztah byl přitom dosud zkoumán zejména jako rozpor mezi celosvětově volným obchodem a fragmentací světové ekonomiky do vzájemně soutěžících bloků. S nástupem globalizace a definitivním zostřením globální konkurence $\mathrm{v}$ její poslední vlně se však multilateralismus i regionalismus výrazně proměňují. Spolu s těmito proměnami se mění i jejich vzájemný vztah. Na základě studia nového regionalismu, který vlivem globalizace spěje k stále větší komplexnosti a otevřenosti, se zdá, že regionalismus a multilateralismus lze chápat jako dvě kompatibilní dimenze širších snah o celkovou ekonomickou reformu globalizovaného světového řádu. Ten se dnes formuje skrze hlubokou a transparentní globální governance (WTO) a globální sít' komplexní dohod o ekonomické liberalizaci (nový regionalismus). Vývoji jejich interakce a podmínkám nového multi-dimenzionálního uspořádání se věnuje tento článek.
\end{abstract}

Klíčová slova: Globalizace; multilateralismus; regionalismus.

\section{Globalization, Multilateralism, Regionalism: from dilemma to multi-dimensionality}

\begin{abstract}
Globalization, multilateralism and regionalism are the most significant tendencies of today's world economy. Their mutual relation has bee so far studied mainly as a dilemma between globally free trade and world economy's fragmentation through competing trade blocks. With the upsurge of globalization and sharp global competition in globalization latest wave, multilateralism and regionalism has, however, changed markedly. Subsequently, their mutual relations have changed as well. Based upon the study of New Regionalism, which leads towards more complex and open trade agreements, it seems that multilateralism and regionalism can be understood as compatible dimensions of broader efforts on an economic reform of globalized world order. It is, today, formed by a deep and transparent global governance (WTO) and a global network of complex economic integration agreements (New Regionalism). The aim of this article is to study the development of their interaction and conditions of their multi-dimensional coexistence.
\end{abstract}

Key words: globalization; multilateralism; regionalism.

JEL classification: F02, F13, F15, F59 